\title{
The Role of Private Planning Firms in Provision of Public Spaces in Planned Residential Neighbourhoods: The Case of Dar es Salaam City and Morogoro Municipality, Tanzania
}

\author{
Marco Burra, Wilfred G. Kazaura, Mswani Laurent \\ Department of Urban and Regional Planning, School of Spatial Planning and Social Science, Ardhi University, Dar es Salaam, \\ Tanzania \\ Email: wkazaura@yahoo.com, marcoburra@hotmail.com,mswanilaurent@gmail.com
}

How to cite this paper: Burra, M., Kazaura, W. G., \& Laurent, M. (2019). The Role of Private Planning Firms in Provision of Public Spaces in Planned Residential Neighbourhoods: The Case of Dar es Salaam City and Morogoro Municipality, Tanzania. Current Urban Studies, 7, 427-448. https://doi.org/10.4236/cus.2019.73021

Received: May 30, 2019

Accepted: September 21, 2019

Published: September 24, 2019

Copyright (๑) 2019 by author(s) and Scientific Research Publishing Inc. This work is licensed under the Creative Commons Attribution International License (CC BY 4.0).

http://creativecommons.org/licenses/by/4.0/

\begin{abstract}
This paper aimed at examining the spatial allocation of public spaces and their standards in newly planned neighbourhoods as implemented by the private planning firms, and their effect to local communities or users. The paper specifically examines and analyses the spatial distribution of public and open spaces and explores the planning standards used by private planning firms in implementing the various planning schemes in Dar es Salaam City and Morogoro municipality. Methodologically, a systematic account was made of the research process, methods and data collection tools linked and detailed studies were made in the selected cases. Comparisons were made with the National space standards provided in the Urban Planning Act; and the level of adherence to planning standards in provision of public spaces was analysed. It was found that public spaces were provided and majority of the firms have adhered to planning standards. Serious omissions were observed; however, with regard to the provision for play fields which were provided in primary and secondary schools, no provision for free public play fields and sport grounds was made in the cases investigated. The paper concludes that despite the involvement of the private planning firms by the government in providing serviced land to the people, there is still a challenge of observing requirements for public spaces, albeit in varying categories and sizes according to the indicative planning standards. Thus, provision of public spaces as public or social goods is generally compromised. The paper recommends that more open spaces, parks and play fields should be provided in the detailed planning schemes, using participatory approaches among Councils, communities, institutions and individuals who shall be given mandates to manage
\end{abstract}


them. Enforcement of the planning standards during approval and implementation of the newly planned residential neighbourhoods by the organs such as Municipalities, City and Urban planning authorities is necessary to ensure success. Private planning firms should be given mechanisms to adhere to the provision of public spaces and the required standards to enable the public at large to utilize these spaces as public goods for the betterment of communities.

\section{Keywords}

Communities, Planning Schemes, Public Open Spaces, Private Planning Firms, Planned Residential Neighbourhoods, Planning Authorities, Space Standards

\section{Introduction}

Tanzania has witnessed, among other things, a growing demand for planned and serviced land in urban areas. The National Land Survey (2015) specifies that the shortage of surveyed plots is acute in the fast growing urban centres of the country such as Dar es Salaam, Arusha, Morogoro, Mbeya and Mwanza. The survey shows that in 2011/12, the demand for new housing plots was estimated to be 157,000 while in the same financial year, only 11,146 plots were surveyed giving a discrepancy of 145,854 plots (URT, 2015). In response, the planning authorities have attempted to reduce the chronic gap between demand and supply of planned land whereby the government allowed, under the Urban Planning Act (2007), other stakeholders particularly the private and popular sectors to take part in land development through planning, surveying and serviced land delivery. Urban planning policies have incorporated the idea of participatory planning as strategic approach and alternative that initiates the involvements of private companies and popular sectors in land delivery systems in Tanzania.

Government efforts to plan, survey and allocate plots to prospective applicants have not been able to meet the demand for plots. The 20,000 plots project report of 2002 to 2006 noted that in between 1990 and 2001, Dar es Salaam City Council and the Ministry of Lands, Housing and Human Settlements Development received 243,473 applications for residential plots in Dar es Salaam, but only 8029 plots were surveyed and allocated (Kasala \& Burra, 2016). The central and local governments' capacity to plan, survey and service land and to provide basic infrastructure and community services kept on diminishing in recent years. The fundamental initiatives in the local government roles in urban planning take place with the engagement of private and popular sectors in provision and delivery of serviced plots in urban areas.

It is observed that Public-Private Partnership (PPP) approach in Tanzania is not yet adequately researched as yet, but it is a generally accepted concept in community and the private sector collaboration that roles to execute land related 
activities and provision of public spaces can be achieved well. As roles are shared, this reduces the government burden as a sole actor in land delivery, plan implementation and in-service provision. While current public policies support application of PPPs in land delivery and plan implementation, the mechanism for establishing the partnership, rules governing the partnerships and the way partners perform their roles are not yet described and clarified (Kasala \& Burra, 2016).

It is further observed that involvement of the private planning firms in providing serviced land to the urban population has proven a positive result. However, the most challenging part includes adherence of planning standards for the provision of public spaces in the planned neighbourhoods. The private firms tend to underestimate or ignore the public spaces as they are non-profitable in land business. The government has paid a little attention in analysing the impacts of outcomes for the private-initiated planning schemes. Among the outcome variables are provision of public spaces and their adequacy to serve urban residents as required by the planning regulations.

Literature reveals that engagement of private firms in urban land delivery has a potential role, but the actual practice of the private sector in land delivery and provision of open/public spaces should be clearly defined (Lefebvre, 1991). The role of the private sector in land delivery needs to be examined, as government creates enabling environment for the private firms to follow standards and codes in land delivery systems. These aspects constitute the focus of this paper.

\subsection{Objectives}

The aim of this paper was to examine the role of private planning firms in providing public open spaces in the planned residential neighbourhoods. In detail, the study identifies and analyses the spatial distribution of public and open spaces in newly planned residential neighbourhood, documents the planning standards used by private planning firms in allocating public and open spaces. It analyses the contribution of private planning firms in providing public spaces in newly planned residential neighbourhoods, and recommends on effective measures for enforcement of the planning standards during approval and implementation of the newly planned residential neighbourhoods.

\subsection{Methodology}

A systematic research process, methods, and case study strategy were adopted. The open-ended and closed questionnaires were adopted in executing the study. The process included physical visits to private firms involved in land delivery, site visits in implemented neighbourhoods in Dar es salaam City and Morogoro Municipality; together with interviews with officials in the planning firms. Dar es Salaam is the largest city and has the highest concentration of projects by private planning companies while in contrast, Morogoro is a provincial city with less dynamics of urban growth. The research process included preparation of 
specific tasks in specific time frame for pre-field work, during field works and post field works. First was initiated by obtaining the list of registered private firms dealing with planning and implementation of residential neighbourhoods in Dar es Salaam and Morogoro. About 39 companies were engaged in preparation of detail plans in Dar es Salaam and Morogoro. Five companies were selected in Dar es Salaam and one company in Morogoro as case studies. The selection of the firms for detailed study was based on the criteria that:

1) The firm should have been engaged in preparation of detail plans in either or both sites located in Dar es Salaam and Morogoro.

2) The company duration period in preparation of detail plans should be five years and above, and

3) The firm should have plans which have been approved by Director of Physical Planning at the Ministry of Lands Housing and Human Settlement Development.

The official interviews that were carried out by researchers included face to face interview with Directors of private planning firms, the Director from the Ministry of Lands and Municipal Councils within the selected case studies. Table 1 presents the private firms which were officially visited and the officials were interviewed. Mapping of the public spaces was done by obtaining the approved Town Planning Drawings (TPs) done by the private firms in order to show their location, spatial distribution within the neighbourhoods. Finally, the TP drawings were digitized in GIS software to facilitate spatial analysis.

Data analysis involved assessing the provision of public spaces depending on the size or area coverage and population to be served. New neighbourhood plans and maps were scanned and digitized for further analysis using GIS tools. The same tools determined the percentages of road reserves, open spaces, conservation areas, play fields and parks or gardens and cemeteries or burial places. The analysis in each neighbourhood has also indicated the adherence of standards provided in Town Planning Space Standards and Regulations.

The approach of the study was initiated by obtaining the list of registered private

Table 1. Selected firms and plans for the study.

\begin{tabular}{cccc}
\hline S/n & Name of Firm & $\begin{array}{c}\text { Location of the } \\
\text { project areas }\end{array}$ & Selected plans for study \\
\hline 1. & Ardhi Plan Ltd & Kigamboni & $\begin{array}{c}\text { TP.No. TEM1/34/082012 } \\
\text { TP.No. TEM1/133/082012 }\end{array}$ \\
2. & Makazi Consult Limited & Temeke & TP.No. 19/TEM/112/082013 \\
3. & City Plan Consultants (T) Ltd & Kinondoni & TP. No. 13/KNC/10/082010 \\
4. & Makazi Solution (T) Ltd & Ilala & TP. No. ILA/1/34/082012 \\
5. & T/A Mpoki Enterprises & Morogoro & $\begin{array}{l}\text { TP.No. 10/MOG/ } 395 / 042013 \\
\text { TP.No. 10/MOG/ 408/092013 }\end{array}$ \\
\hline
\end{tabular}

Source: Ministry of Lands, 2018. 
firms dealing with planning and implementation of residential neighbourhoods in urban areas. The registration bodies included Architectural and Quantity Surveyors Registration Board (AQRB) whereby the researchers obtained lists of Architectural and Quantity surveying firms, Town Planners Registration Board (TPRB) which provided list of Town planning firms; National Corporate of Private Surveyors (NCPS) which provided list of Land surveying firms; and Engineers Registration Board (ERB) which provided list of Engineering firms.

Case studies were used as windows into the workings of the planning process; and a gateway to understanding and illustrating the extent and nature of planning experience by the private planning firms. At the outset, one of our goals was to disseminate through research information, newly planned residential neighbourhood case studies: private firms' involvement in the planning; development and analysis of provision of public spaces in the implemented plans over a period of time.

The research was qualitative in nature but involved the use of quantitative data and mapping techniques and tools, interviews with planning firms and officials in the Planning Authorities. The research process involved: identification of planned areas in liaison with relevant Local Authorities; land acquisition, approved town planning drawings and, and approval, allocation of areas for roads to improve accessibility, open and public spaces and marketing of planned and serviced land (Map 1).

\section{Literature Review}

This chapter provides literature review, theoretical aspects of the study and conceptualizes the role of open spaces in provision of public spaces in urban land delivery. It focuses on land use planning, implementation and development. It further discusses relevant theories, defines key terms and concepts and describes key variables of the study as they emerge from literature review. With regard to provision of public spaces in land use planning, planning and space standards, public participation, theory of place in public space and theory of urban design have been discussed.

\subsection{Overview of Public Space Provision}

In popular parlance, public space is all around us, is outdoor leisure center, a place where children play, a place where people enjoy sports and other recreational activities like making stories. The key themes in the literature on urban public space, considering how the term is defined, its social and political significance and use are discussed in scholarly literature (Brown, 2004; UN-Habitat, 2016). In planning perspective, these spaces have been historically defined as "open space", meaning streets, parks, recreation areas, plazas and other publicly owned and managed outdoor spaces in built environment (Nano, 2015). However, public spaces are more than open spaces; they include "semi-enclosed spaces" example street facades, religious facilities and other buildings used by 


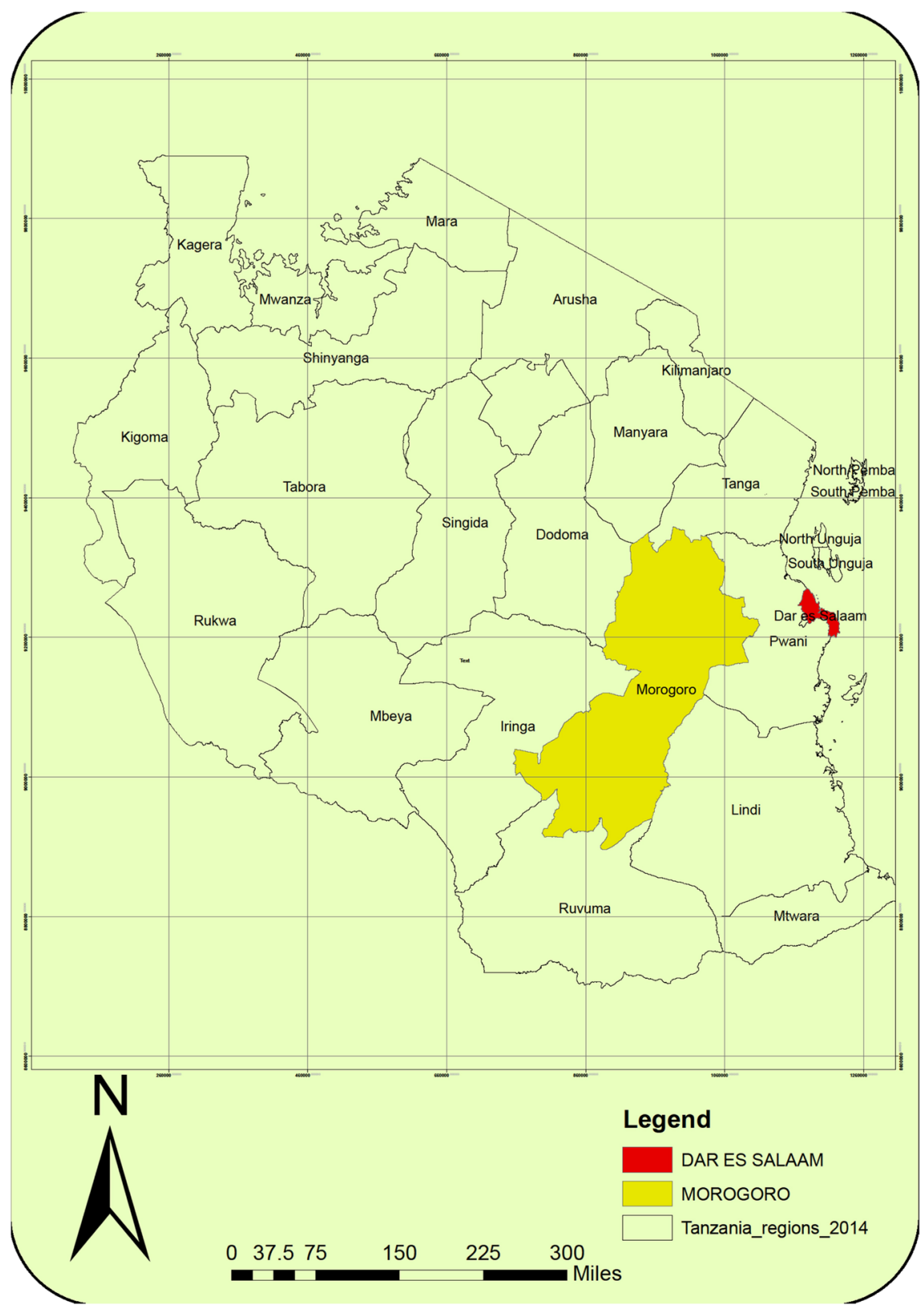

Source: MLHSD Department of Survey and Mapping, May 2017.

Map 1. Location map for Dar es Salaam and Morogoro.

public (Madanipour, 2010).

UN-Habitat (2015), defined public space as all places publicly owned or of public use, accessible and enjoyable by all for free and without profit motive. Public space takes many spatial forms, including parks, the streets, sidewalks and footpaths that connect, playgrounds of recreation, market places, but also edge space between buildings or roadsides which are often important spaces for the urban poor and in many contexts, beaches are also public spaces (UN-Habitat, 2016). A public space is a space which is owned by all members of the public, with equal access and participation (Alubo, 2011). In public spaces we are all 
equal, in the sense that we can all exercise our shared right to the city without having to display neither our social status nor our ability to spend money. But public spaces are also the embodiment of equity (Garau, 2014).

\subsection{Size and Importance of Public Spaces}

Urban public space may constitute a quarter to a third of the land area of cities, but its economic role is largely ignored. In Tanzania, for example, it is estimated that $81 \%$ of the workforce is employed in the informal sector, many of whose livelihoods depend on access to public space (Brown, 2004). According to Brown (2004), the term urban public spaces means all space that is not clearly delineated as private, where there is at least a degree of accepted and legitimate public or community use (Woolley, 2003). The term also recognizes that urban public space and its use is a manifestation of social and cultural norms and political practice that both results from and determines concepts of social order and land use promoted by the dominant political elite (Graham \& Healey, 1999). The term land development in this study is used to mean planning, surveying, and providing for vehicular accessibility improvement. Public spaces are central concern of urban planners for centuries (Rapaport, 1982). Recently, public space has become a focus for sociologists, geographers, political scientists, economists; interested not only in how such places are built and managed, but also in how they function socially, economically and politically (Gehl, 2011).

\subsection{Guidelines of Public Spaces Provision in Tanzania}

In the Urban Planning Act of 2007, with regards to public space standards and provision, the Act defines them in the $3^{\text {rd }}$ Schedule in section (F), arguing for providing the reservation of land as open spaces, whether public or private parks, sports grounds and playing fields (URT, 2007). The provisions should be for the preservation of views, prospects and the amenities of places and features of natural beauty or interest. Rather than defining the areas nothing was stipulated clearly to be taken as a legal stand. The National Land Policy of 1999, stipulates in its Section 6.6; the protection of public open spaces and urban land for public uses (URT, 1999). The section also defined the public spaces as sites set aside in urban areas for public activities such as schools, public utility easements and other community facilities. The policy is aware of its invasion by private developers for other activities to the disadvantage of the general public. In dealing with such, from the legal-economic point of view, it provides statements in its section 6.6.1 (ii) that all sites for public activities in towns shall be licensed to appropriate authorities including $\mathrm{CBOs,} \mathrm{NGOs} \mathrm{and} \mathrm{others} \mathrm{who} \mathrm{will} \mathrm{be} \mathrm{required}$ to develop and maintain the sites for prescribed public uses. By doing so, the sustainability of these public spaces can be achieved (URT, 1999).

As cited by Angel (2012) in Urban Planning Act (2007), public spaces are designed and planned according to the standards proposed by the planning authority. The Local Government Regulations suggests the public space to be 45 
percent of the total urban land and should be owned by all residents and equally used or accessed by the community members.

\subsection{Approaches of Public Spaces Provision in Urban Area}

Public spaces are termed as key element of design for effective functions of the city. The public spaces attribute should be accessible and strategically located to facilitate communal uses. They should be found in a place where by individual or large community can reach by their willing to use (Ghavampour et al., 2014).

\subsubsection{Sensory Design and Adoption}

Urban design and Architecture indicate a visual and sensory relationship between people and the built and natural environment. For example, in the city of San Diego in the US construction of Balboa Park and mission, Bay Park modified the natural environment but created unique public and civic paces that are still much used and admired. In the case of public spaces, the theory explains the importance of open space and recreation (Lonsdale, 2008). Open spaces should be usable for play, recreation and social cultural activities. Public spaces should be easy accessed by everyone in the development it serves by locating small parks and play areas in central accessible locations. Thus, it is recommended to develop public space with a unique character, specific to its site and use (Lonsdale, 2008). The concept of public space and its manifestation are discussed in a wider framework from different views and these are political philosophy, urban planning, and architectural interpretation (Gaubatz, 2008). For the philosophers, the public space is a social realm, an arena of human action and communication. It is public in the sense that it is accessible to all and, under ideal conditions, directed to matters of common concern (Lefebvre, 1997). The symbolic importance of urban public places is demonstrated by pictures and visual characteristics often found in public relations brochures (Goodsell, 2013).

\subsubsection{Urban Land Delivery}

"Land delivery" refers to the way agents have access to land. Each type of land delivery or land delivery channel is characterized by 1 ) its organization and steps in the delivery process (from initial conversion of non-residential land into residential land to the occupation of the developed land by its final user), 2) the stakeholders involved in the delivery process, and 3) the tenure held over land, land prices (whether market or non-market based), and the provided services (whether plots have water and electricity). Land delivery channels form a system so that any change affecting one segment within one land delivery channel has impacts on other channels (Lefebvre, 1991). Urban land delivery in particular context means a legal process of land acquisition and compensation, planning and surveying, provision of infrastructures, marketing, and allocation and registration by the government and/or private agencies. The process extinguishes all proprietary and jurisdictional rights, titles, or other interests vested in the traditional authority or any other person (Alubo, 2011). 


\subsection{Private Sector's Response in Land Delivery}

The private sectors' involvement in land development through the production of planned, survey and serviced plots began way back in 2002 (Kasala \& Burra, 2016). For the period ranging from 2002 to 2012 the private sector had delivered about 68,000 plots in Dar es Salaam region alone. Later, a total of other 32,650 plots were produced between 2013 and May 2015. This means from 2002 to date the private sector has produced more than 100,000 plots in Dar es Salaam and other regions (Kasala \& Burra, 2016). Such a substantial supply of planned and serviced plot was made possible through the involvement of more than 108 private firms, in association with local authorities, Commercial Banks, Public Pensions Funds, Private companies, and Ministry of Lands, Housing and $\mathrm{Hu}-$ man Settlements Development to mention but a few. Whereas the firms involved were town planning, land surveying and engineering by profession, key players on the Banking sectors were Commercial and Rural Development Bank (CRDB), Azania, and Women Development Banks (Kasala \& Burra, 2016). In principle, the private Town Planning firms have been initiating the planning process that ends up with the delivery of approved town planning drawings. Approved Town Planning drawings are then used to engage land surveyors to survey land according to the approved town planning drawings. The completion of survey activities including approval of survey plans, marks the beginning of engineering activities. The later, deals with opening up and/or improving vehicular access into the planning area (Kasala \& Burra, 2016).

\subsection{Private Sector in Public Spaces Provision}

The provision of public spaces by private planning firms in urban areas is hinged on the concept of involvements in urban land delivery (Spring Term, 2012). The process depends much on the planning space standards, institutional and legal framework; capacity building, preparation of detailed planning schemes and the public participation (Alison, 2004). Policy formulation, institutional and legal framework can be carried out when local community, public and private sectors are involved. Policy formulation implies developing a set of ideas or plans that are agreed officially by the group of people or government (Madanipour, 2003). The encouragement of community and private sectors participation, it makes them to understand the motives behind having a planned and surveyed land in formulated policies for public spaces provision (URT, 2000).

Provision also depends on public interest to make socialization of people within the community, supporting sports and games and public meetings. Spaces consider public interest by adhering to public space standards, whereby the standards lead to the make a public space comfortable place for users (Ghavampour et al., 2014).

Public spaces must be distributed by considering the compatibility with other land uses and the accessibility by walking distance from residential areas or from the public transport according to planning space standards (URT, 2012). Provi- 
sion of public spaces in newly planned residential areas is conceptualized on urban land delivery system in Tanzania, the concept public-private partnership and capacity building for the non-state actors, including the private planning firms (Figure 1).

Outsourcing the professional services takes place when some of local government's roles are performed by a private licensed company under agreed terms and conditions (Bodnar, 2015). Contracting to consultants' best work in municipal councils is due to unstable own sources of revenue and complement central government allocated budget. It also applies to the municipalities with a limited number of land experts and inadequate equipment. Proper by-laws to guide the formulated partnership in executing projects to competent private companies need to be well coordinated among actors. As indicated in Figure 1, contracting to private consultants has to be analysed to find out what type of services, competence, and capacities are required in order to make urban land delivery efficiently achieved.

Participatory planning happens when the community and other key players become involved in land use planning and development and for service provision (Bodnar, 2015). Contrary to the top-down planning approach, participatory

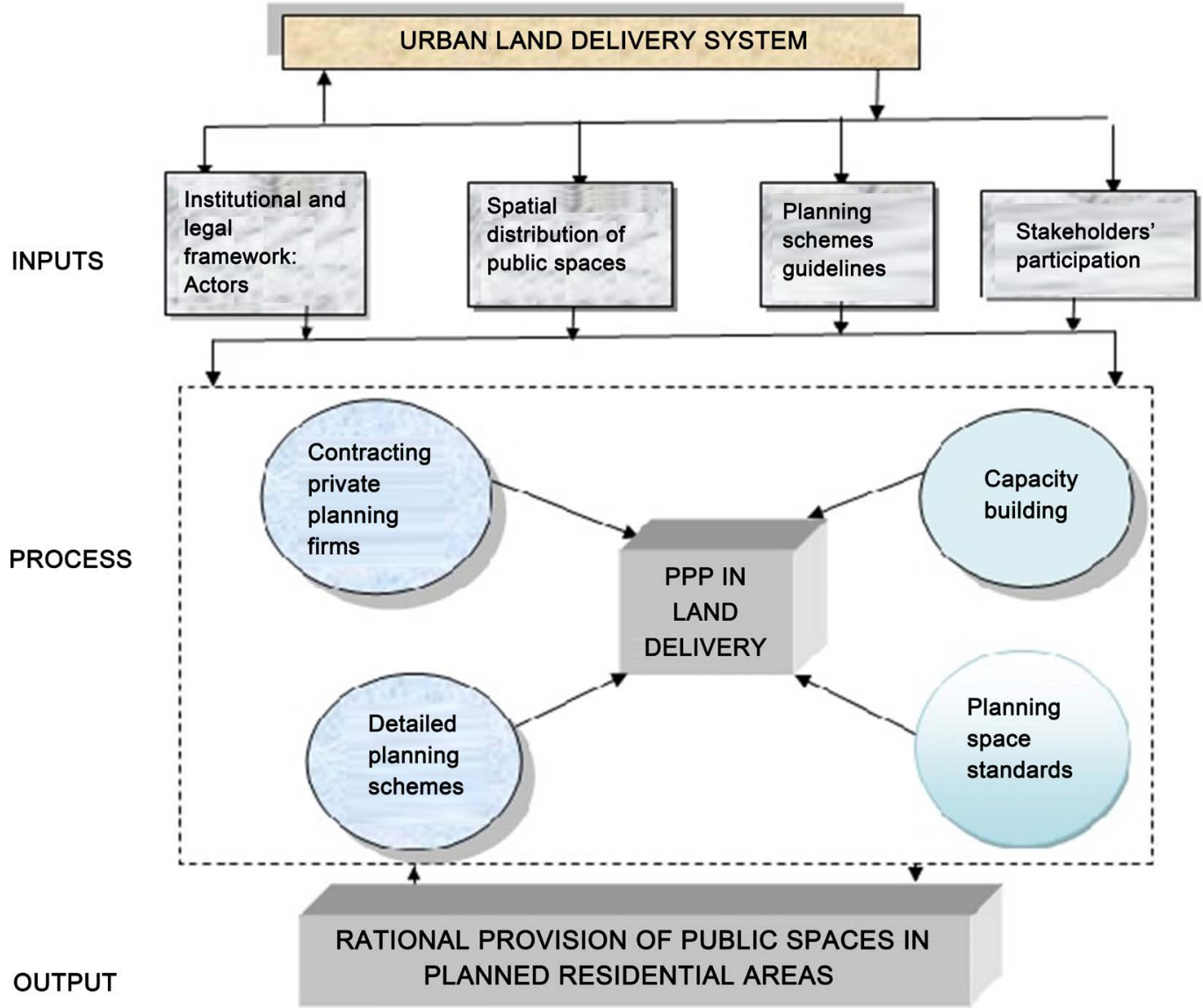

Source: Researchers' construct, 2018.

Figure 1. Provision of public spaces in newly planned residential areas: a conceptual framework. 
planning identifies, sensitizes and encompasses various actors, such as public authorities, citizens, NGOs and private firms who apart from sharing the planning ideas, exchange expertise, encourage cost-sharing mechanisms and minimize resistance to public land use planning. When utility agencies become informed about planning objectives, they work harder to supply the service to meet the demand of the community (Bodnar, 2015). Participatory planning is thought to be a democratic way of planning as it determines the way planning can be achieved with resource available. Thus, participatory planning is likely to be the ideal way to plan and develop urban areas (Kasala \& Burra, 2016).

\section{Results, Findings and Discussion}

The section discusses the provision of public spaces in the planned neighbourhoods, their coverage and the adherence of standards. Evaluation was made for different categories of public open spaces, whereby, as indicated in Urban Planning Act No. 82007, there are five major types of public open spaces required to be indicated in detailed planning scheme including open spaces, cemeteries, play fields, parks and road reserves.

\subsection{Distribution of Public Open Spaces: Case Studies Analysis}

The assessment for the provision of public spaces was made for layout plans such as Town Planning (TP) drawing No. 19/TEM/112/082013 of Muyuni area in Temeke municipality, TP drawing No. TEM1/34/082012 Golani Kimbiji and TP drawing No. TEM1/133/082012 of Yale Yale Puna area in Kigamboni Municipality; TP drawing No. 13/KNC/10/082010 SalaSala Juu in Kinondoni municipality; TP drawing No. ILA/1/34/082012 Mbondole area in Ilala Municipality; TP drawing No. TP.No. 10/MOG/395/042013 Makunganya Mawasiliano West and TP.No. 10/MOG/408/092013 Kiegeya Ngerengere area in Morogoro Municipality.

\subsubsection{Mbuyuni Layout Plan in Temeke Municipality}

The layout comprises four types of public open spaces. The first open space is conservation area provided as buffer along the valleys, second is open spaces distributed in the residential communities, third is the neighbourhood park and last is the play fields. As indicated in Map 2, play fields are located in primary and nursery schools specifically for school use but not for public use. Park is located at the central part of the neighbourhood for public use, and open spaces and located in residential and commercial residential plots (Table 2).

The plan covers about 89.9 hectare which is equivalent to a neighbourhood as per area coverage and should serve 2760 people. According to the planning standards, parks and play fields provided in this plan are adequate. However, open spaces and cemetery are underprovided. For open spaces, 100 people should be served by 0.05 -hectare open spaces, and therefore the entire neighbourhood should be provided with 1.4 hectares for open spaces and cemetery should cover 0.5 - 1 hectare. 


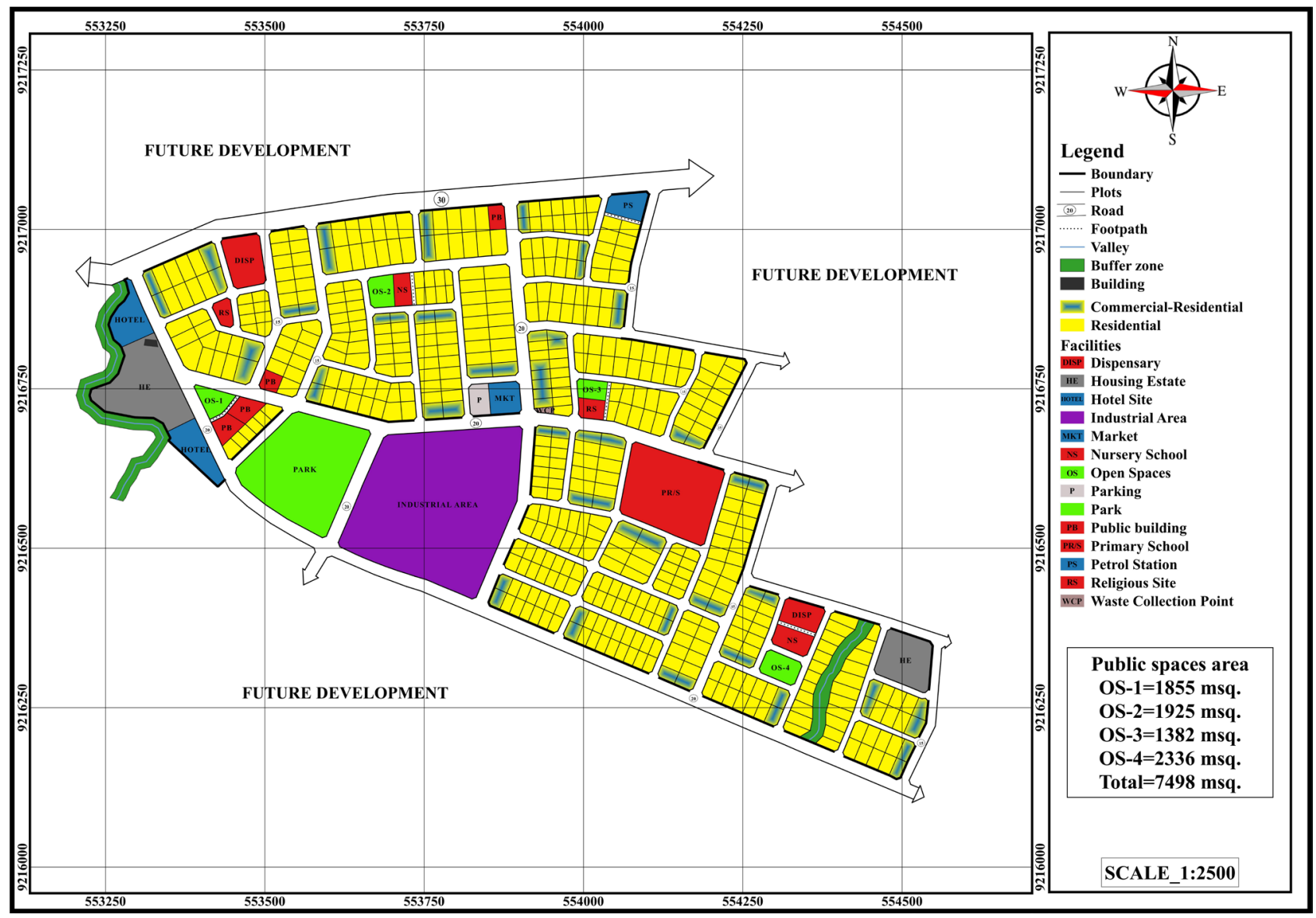

Source: MLHHSD Department of Physical Mapping, May 2017.

Map 2. Spatial distributions of public spaces in Mbuyuni layout plan.

Table 2. Public open spaces in Buyuni TP drawing.

\begin{tabular}{cccc}
\hline S/n & Public open space & Area (hectare) & Percentage\% \\
\hline 1. & Open spaces & 1.2 & 1.33 \\
3. & Cemeteries & 0.7 & 0.8 \\
4. & Parks & 14.6 & 16.2 \\
5. & Play fields & 1.2 & 1.0 \\
6. & Conservation areas & 14.6 & 16.2 \\
& Total & 32.3 & 35.53 \\
\hline
\end{tabular}

Source; Buyuni Town planning drawing in Temeke Municipality.

\subsubsection{Yale Yale Layout Plan in Kigamboni Municipality}

The plan portrays three categories of public open spaces. As presented in Map 3, the first category is open areas along river valley reserved for as conservation of steep slopes and river banks. Other open spaces include graveyards for burial activities and playfields that are equally distributed along primary and nursery schools.

The plan covers about 69.1 hectares and should accommodate 3110 people 


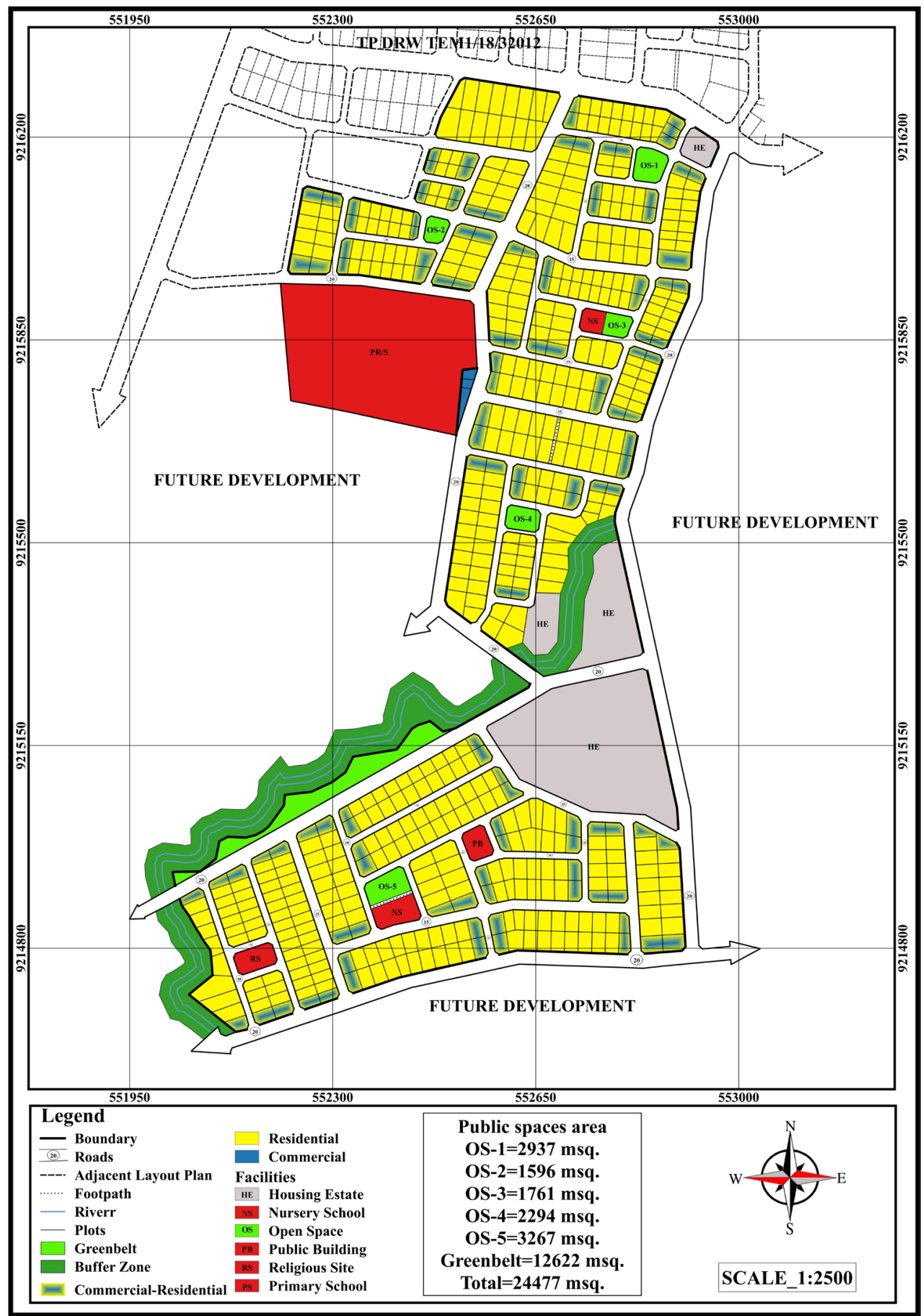

Source: MLHHSD Department of Physical Mapping May 2017.

Map 3. Spatial distributions of public spaces in Yale Yale layout plan.

which is equivalent to neighbourhood as per area coverage. As indicated in Table 3, the area covered by the open spaces are adequate whereby, the space required is 0.05 -hectare and area provided for open spaces is 1.56 hectares. On the other hand, the area with should be provided cemetery is higher than the area required. The plan has advantage of conservation areas for river valley which can 
be modified to recreation activities Therefore, this plan adhered the space standards. However, some of potential public spaces like open play grounds, parks and recreational areas are not provided.

\subsubsection{Golani Layout Plan in Temeke Municipality}

The layout comprises two types of public open spaces; first is open spaces distributed in the residential communities and second is the play fields. As indicated in Map 4, play fields are located in primary and nursery schools specifically

Table 3. Public open spaces in Yale Yale TP drawing.

\begin{tabular}{cccc}
\hline SN & Public open space & Area (hectare) & Percentage\% \\
\hline 1. & Open spaces & 1.8 & 2.6 \\
3. & Cemeteries & 0.89 & 1.2 \\
5. & Play fields & - & - \\
6. & Conservation areas & 14.8 & 16.9 \\
& Total & 17.49 & 20.7 \\
\hline
\end{tabular}

Source: Yale Yale Town planning drawing in Temeke Municipality.

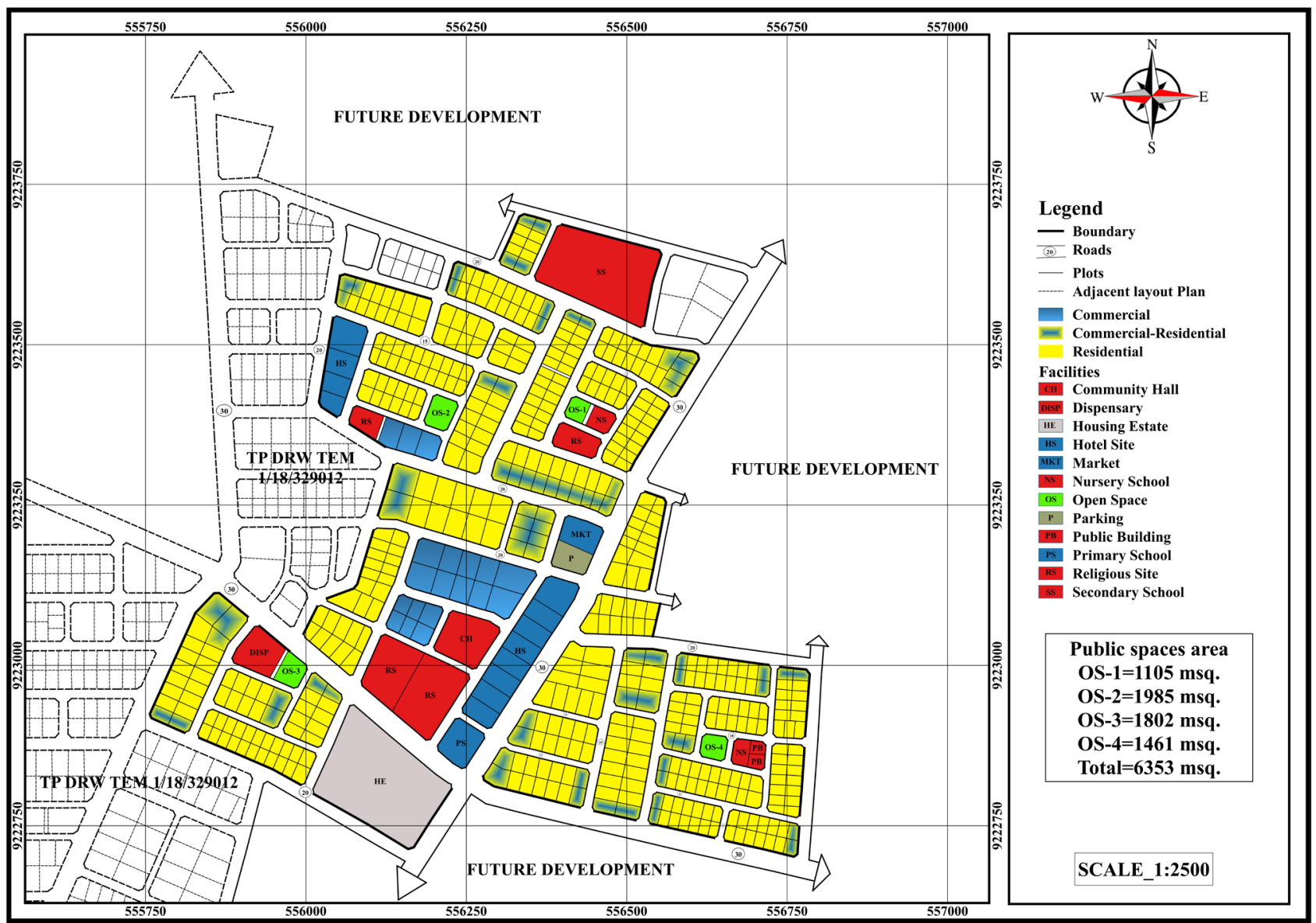

Source: MLHHSD Department of Physical Mapping May 2017.

Map 4. Spatial distributions of public spaces in Golani layout plan. 
for school use but not for public use. Open spaces and located in residential and commercial residential plots.

The plan covers about 84.5 hectare and should accommodate 2867 people which is equivalent to neighbourhood as per area coverage. The area covered by the open spaces is adequate whereby, the space required is 0.05 -hectare and area provided for open spaces is 1.12 hectare. This plan adhered the open space standards. However, Neighbourhood Park is not provided. Play fields are provided in schools however, sometimes they have limitations and are not easily accessible by the general public.

\subsubsection{Mbondole Layout Plan in Ilala Municipality}

The plan portrays three categories of public open spaces. As indicated in Map 5, the first category is open space used for public play grounds located in the central part of the neighbourhood. The second category includes playfields distributed along nursery schools, and last part is the open spaces which are distributed in residential areas (Table 4).

The plan covers about 45.2 hectare projected to serve 2510 people which is equivalent to half neighbourhood as per area coverage. The plan cover about

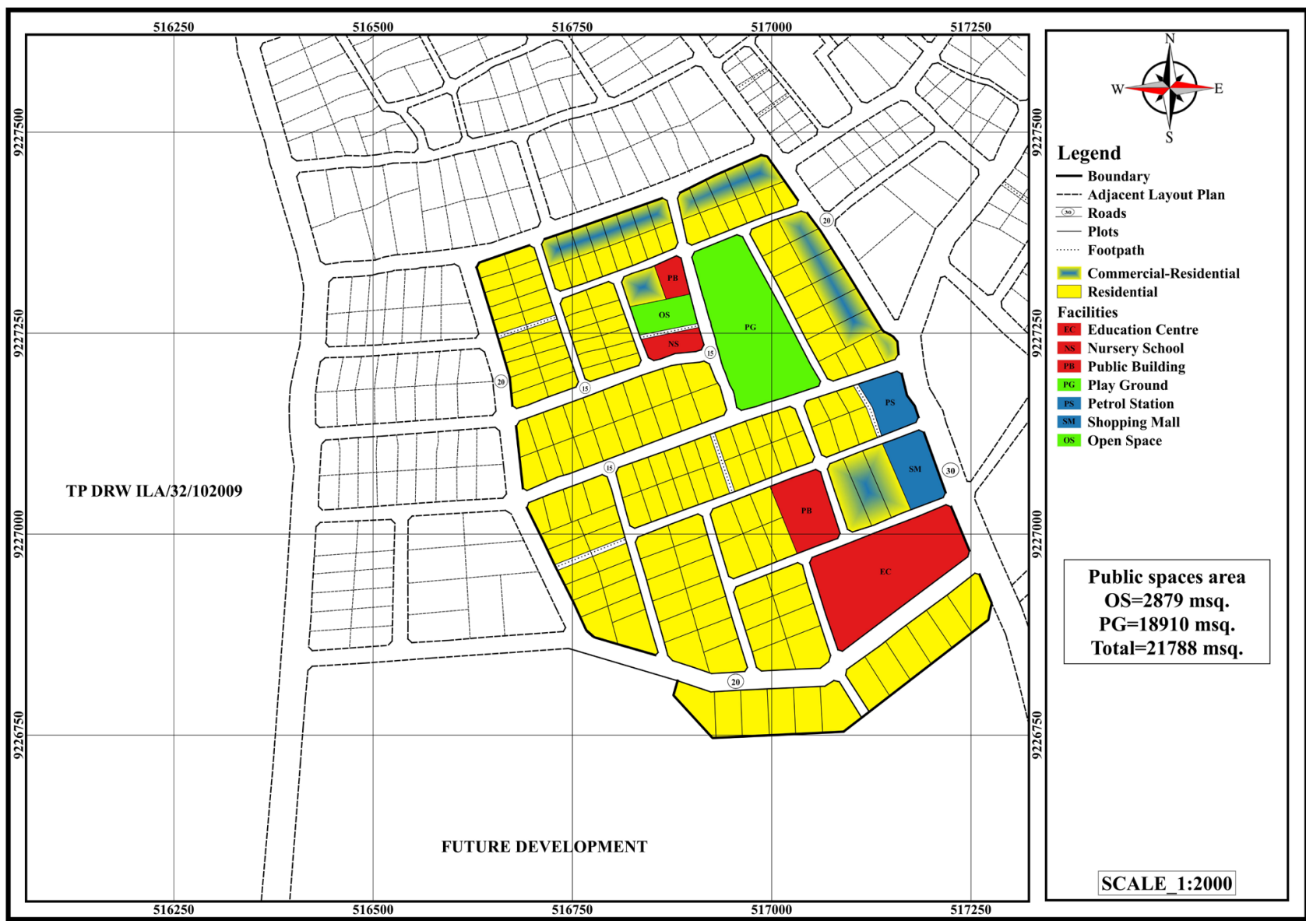

Source: MLHHSD Department of Physical Mapping May 2017.

Map 5. Spatial distributions of public spaces in Mbondole layout plan. 
1.12 hectares for open spaces, and is provided with 1.98-hectare open spaces. Therefore, open spaces provided are inadequate compared to the Town Planning standards. Cemetery is missing, but sometimes can be shared with adjacent neighbourhoods. Neighbourhood Park is provided to enhance gardening and community gathering. Playfields are provided in schools. However, sometimes have limitations and are not easily accessible by the general public.

\subsubsection{Makunganya Mawasiliano West Layout Plan in Morogoro Municipality}

The plan portrays four categories of public open spaces. As indicated in Map 6,

Table 4. Public open spaces in Mbondole TP drawing.

\begin{tabular}{cccc}
\hline S/n & Public open space & Area (hectare) & Percentage\% \\
\hline 1. & Open spaces & 1.42 & 1.57 \\
2. & Open play ground & 2.7 & 3.1 \\
3. & Conservation areas & 2.2 & 3.5 \\
& Total & $\mathbf{6 . 0 2}$ & $\mathbf{8 . 1 7}$
\end{tabular}

Source: Mbondole Town planning drawing in Ilala Municipality.

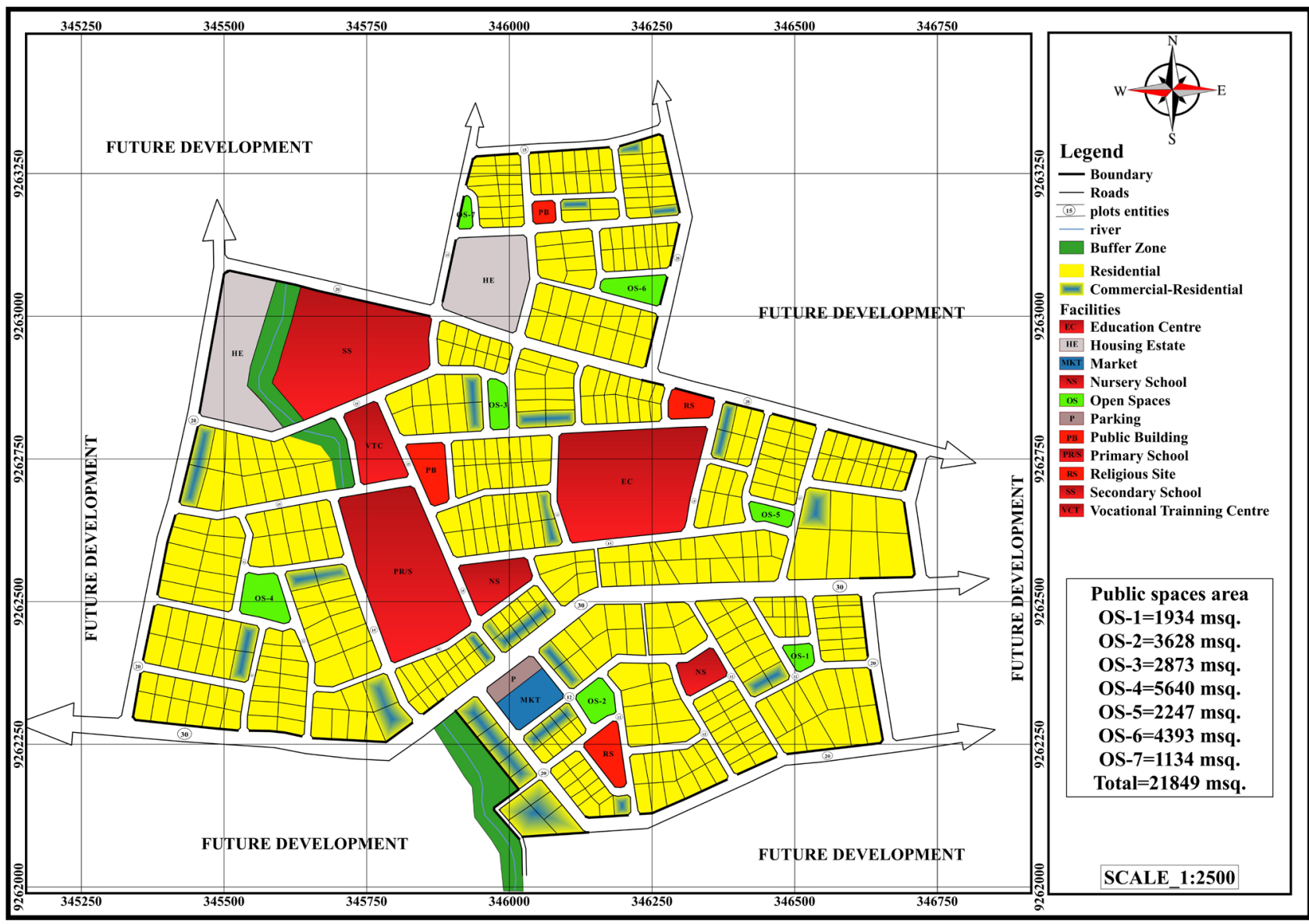

Source: MLHSD Department of Physical Mapping May 2017.

Map 6. Spatial distributions of public spaces in Makunganya Mawasiliano layout plan. 
Table 5. Public open spaces in Makunganya Mawasiliano TP drawing

\begin{tabular}{cccc}
\hline S/n & Public open space & Area (hectare) & Percentage\% \\
\hline 1. & Open spaces & 1.92 & 1.75 \\
2. & Parks & 0.5 & 0.42 \\
3. & Play fields & - & - \\
4. & Conservation areas & 3.2 & 3.01 \\
& Total & 5.62 & 5.18 \\
\hline
\end{tabular}

Source: Makunganya Mawasiliano Town planning in Morogoro Municipality.

the first category is open reserved and conservation of steep slopes and river valleys. Second category is graveyard and burial spaces, third category is for play fields distributed along primary and nursery schools, and last category includes open spaces distributed in residential areas (Table 5).

The plan covers about 115.2 hectare to serve 4210 people which is equivalent to neighbourhood as per area coverage. The plan covers about 1.92 hectares for open spaces, which is a bit less compared to planning standards which requires about 2.1 hectare open spaces. Neighbourhood Park is provided to enhance gardening and community gathering. Play fields are provided in schools. However, sometimes they have limitations and are not easily accessible by the general public. Cemetery is missing, but sometimes can be share with adjacent neighbourhoods.

\subsubsection{Kiegeya Ngerengere Layout Plan in Morogoro Municipality}

As indicated in Map 7, Kiegeya layout portrays three categories of public open spaces. First category is open reserved and conservation of steep slopes and river valleys. Other open spaces are for and play fields distributed along primary and nursery schools, and others are located at the central parts of residential areas (Table 6).

The plan covers about 102.2 hectare and shall serve 4099 people which is equivalent to neighbourhood as per area coverage. The plan cover about 2.62 hectares for open spaces, which is a bit higher compared to space standards which requires provision of 2.04-hectare. The area for cemetery is adequate and can be shared by the adjacent neighbourhoods. Neighbourhood Park is provided to enhance gardening and community gathering. Play fields are provided in schools however, sometimes have limitations and are not easily accessible by the general public.

\subsection{Summary of Adherence to Planning Standards by Planning Firms}

Table 7 indicates the level of adherence to planning standards in provision of public spaces for the detail planning schemes prepared by the private planning firms. Generally public spaces are provided and great percentages have adhered to planning standards. Serious omission is for play fields which are provided in primary and secondary schools, but no provision for free public play fields and 
sport grounds. Other public spaces are presented as in Table 7.

\section{Conclusion and Recommendation}

\subsection{Conclusion}

The paper set out to examine and establish the role played by private planning

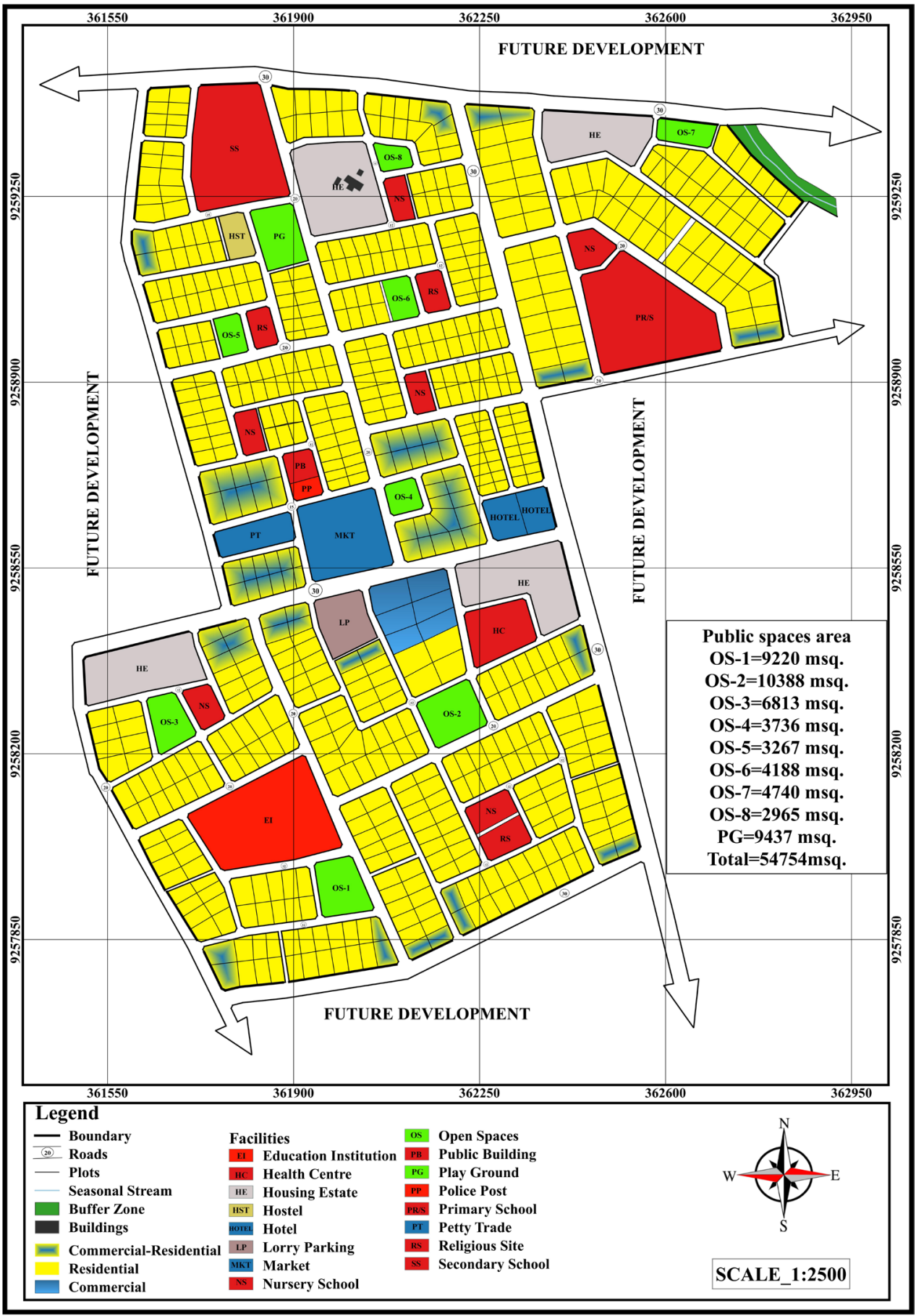

Source: MLHSD Department of Survey and Mapping, May 2017.

Map 7. Spatial distributions of public spaces in Kiegeya Ngerengere layout plan. 
Table 6. Public open spaces in Kiegeya Ngerengere TP drawing.

\begin{tabular}{cccc}
\hline S/n & Public open space & Area (hectare) & Percentage $\%$ \\
\hline 1. & Open spaces & 2.62 & 2.6 \\
3. & Cemeteries & 0.98 & 0.96 \\
4. & Parks & 0.61 & 0.59 \\
6. & Conservation areas & 6.5 & 6.2 \\
& Total & 10.71 & 10.35 \\
\hline
\end{tabular}

Source: Kiegeya Ngerengere Town planning drawing in Morogoro Municipality.

Table 7. Summary of adherence to planning standards.

\begin{tabular}{|c|c|c|}
\hline $\begin{array}{l}\text { Public spaces } \\
\text { provided }\end{array}$ & Adherence to Planning standards & Remarks \\
\hline Open spaces & $\begin{array}{l}\text { Provided for all plans in Dar es } \\
\text { Salaam and Morogoro; but partially } \\
\text { adhered to in Dar es Salaam plans }\end{array}$ & $\begin{array}{l}\text { Less provision of open spaces is observed; } \\
\text { this is sometimes compensated by } \\
\text { conservation areas provided in these layouts }\end{array}$ \\
\hline Cemeteries & $\begin{array}{l}\text { Provided in one plan only. Other plans } \\
\text { have no provision of cemeteries }\end{array}$ & $\begin{array}{l}\text { Cemeteries are larger in required standards; } \\
\text { and can be shared with other neighbourhoods }\end{array}$ \\
\hline $\begin{array}{l}\text { Conservation } \\
\text { areas }\end{array}$ & $\begin{array}{l}\text { Buffer zone sizes adhered to in } \\
\text { almost in all plans }\end{array}$ & Buffer zones standards have been kept \\
\hline Parks & $\begin{array}{l}\text { Are less provided in Dar es Salaam } \\
\text { plans and all standards have been } \\
\text { adhered to in Morogoro plans }\end{array}$ & $\begin{array}{l}\text { Provided only for Morogoro detail plans and } \\
\text { missing in all Dar es Salaam plans. } \\
\text { Should be provided in other layouts } \\
\text { especially in neighbourhood centres }\end{array}$ \\
\hline Playfields & $\begin{array}{l}\text { Not provided and not adhered to in } \\
\text { all investigated cases }\end{array}$ & $\begin{array}{l}\text { Were only provided in schools. Open sport } \\
\text { grounds should be provided according to } \\
\text { planning regulations. }\end{array}$ \\
\hline
\end{tabular}

firms in provision of public open spaces and adhering to planning standards in new residential neighbourhoods. It has been established that despite the involvement of the private planning firms by the government in providing serviced land to urban residents, there is still a challenge of observing planning standards for public spaces, albeit in varying categories and sizes according to the indicative planning standards provided in Urban Planning Guidelines. Allocation of public spaces tends to be underestimated or ignored as they are non-profitable to the private firms. The observations from the investigated cases indicate that there are serious omissions in the provision of playfields which are provided in primary and secondary schools, but no provision for free public playfields and sport grounds has been considered. Parks were provided only for the Morogoro detail plans and are missing in some layouts in Dar es Salaam city. Playfields were not provided and not adhered in all investigated cases in both localities.

Thus, provision of public spaces as public or social goods is generally compromised. This brings to the fore the role of urban planning in ensuring that public spaces are delivered as spaces which are owned by all members of the 
public, for public use, with equal access and participation and enjoyable by all for free and without profit motive. Among the issues noted in both field observations and literature reviews, is the fact that public spaces are essential for a city life like that of Dar es Salaam and Morogoro. Apart from being important for the amenities and resting places the areas are also well used as a source of income by providing services such as leisure, car parks, car wash, ornamental nurseries and also provide spaces for advertisement.

\subsection{Recommendation}

Deriving from the study, public spaces provided should be flexible to the social dynamics to cater for needs of new forms of public that require new spaces for the urban population in general. In the end, urban planning should incorporate stakeholder's involvement and planning principles that need to integrate private and popular sector to meet the social and economic needs of people, whilst at the same time making provision for the high-quality natural, semi-natural and built environments which are needed in the development of fast-growing cities.

It is therefore recommended that planning approval organs such as Ministry for Lands, Municipalities, Cities and urban planning authorities are urged to enforce provision of open spaces, playfields and parks when approving and implementing detailed planning schemes. Private planning firms should be given mechanisms to adhere to the provision of public spaces and make sure the required standards are met before submitting detailed plans for approval. These measures will greatly improve provision of public spaces in detailed planning schemes and their implementation for the public good.

On measures for enforcement of the planning standards; private firms should be guided during planning processes. Rules and regulations should be imposed throughout preparation and implementation of the newly planned residential neighbourhoods, and private firms should make sure all required public spaces are presented in the plan. There is need to strengthen this dimension for sustainable provision and management of public spaces as public and social goods, an aspect that needs to be coalesced into the urban planning practice in the country.

The recommendations are also in line with the Urban Planning Act of 2007, with regard to public space standards and provision, arguing for provision of the reservation of land as open spaces, public or private parks, sports grounds and playing fields. Public spaces are often important spaces for the urban poor, in many contexts and the planning perspective. These spaces have been historically preserved and managed as a common good.

It is further recommended that more open spaces, parks and play fields should be provided in the detailed planning schemes for implementation. Also, collaborative approaches among councils, NGOs, CBOs community and other relevant institutions are very importation for sustainable development of public spaces in urban areas. However, before this exercise is implemented, there is a 
need of identifying, categorizing and defining potential organs that can effectively manage these open spaces. After defining management procedures, the responsible stakeholders should prepare plans that will improve the quality of such open/public spaces. The Municipalities should put proper control on the open spaces, to avoid invasion and abuse, and that open spaces as public goods should serve the residents better to contribute to their well-being.

\section{Acknowledgements}

The authors wish to acknowledge the initiative of the Ardhi University administration and the Swedish International Development Agency (SIDA) for the research grant assistance and guidance that was afforded to them during the development and conducting of the research; and now in disseminating the research results. We also acknowledge the assistance received from the Municipalities and private planning firms who availed data, maps and plans from their companies which have been collaboratively engaged in preparing the detail plans in Dar es Salaam City and Morogoro Municipality.

\section{Conflicts of Interest}

The authors declare no conflicts of interest regarding the publication of this paper.

\section{References}

Alison, B. (2004). Claiming Rights to the Street: The Role of Public Space and Diversity in Governance of the Street Economy. Cardiff: Cardiff University.

Alubo, O. (2011). The Public Space in Nigeria: Politics of Power, Gender and Exclusion. Africa Development, 36, 75-95.

Bodnar, J. (2015). Reclaiming Public Spaces. Urban Studies, 52, 2090-2104. https://doi.org/10.1177/0042098015583626

Garau, P. (2014). Public Space, Think Piece. UCLG Committee on Urban Strategic Planning.

Gaubatz, P. (2008). New Public Space in Urban China. China Perspectives, 4, 72-83.

Gehl, J. (2011). Life between Buildings: Using Public Space (J. Koch, Trans.). Washington DC: Island Press.

Ghavampour, E., Vale, B., \& Aguila, M. D. (2014). Theory of Place in Public Space. Urban Planning, 4, 249-259.

Goodsell, C. T. (2003). The Concept of Public Space and Its Democratic Manifestations. The America Review of Public Administration, 33, 361-383. https://doi.org/10.1177/0275074003254469

Graham, S., \& Healey, P. (1999). Rational Concepts of Space and Place: Issues for Planning Theory and Practice. European Planning Studies, 7, 623-646. https://doi.org/10.1080/09654319908720542

Kasala, S., \& Burra, M. (2016). The Role of Private Partnerships in Planned and Serviced Land Delivery in Tanzania. iBusiness, 8, 10-17. https://doi.org/10.4236/ib.2016.81002

Lefebvre, H. (1991). The Production of Space (D. Nicholson-Smith, Trans.). Oxford: 
Blackwell.

Lefebvre, H. (1997). The Everyday and Everydayness. In S. Harris, \& D. Berke (Eds.), Architecture of the Everyday (pp. 32-38). New York: Princeton Architectural Press.

Lonsdale, R. (2008). Urban Design Element. San Diego, CA.

Madanipour, A. (2003). Marginal Public Space in European Cities. Journal of Urban Design, 9, 267-286.

Madanipour, A. (2010). Whose Public Space? International Case Studies in Urban Design and Development (pp. 237-243). New York: Routledge.

https://doi.org/10.4324/9780203860946

Nano (2015). Public Open Space Categories. London.

Rapaport, A. (1982). The Meaning of the Built Environment: A Non-Verbal Communication Approach. Tucson, AZ: The University of Arizona Press.

Spring Term (2012). Capital Spaces: A Design Guide for London's Public Spaces. Bartlett School of Planning.

UN-Habitat (2015). Global Public Space Toolkit: From Global Principal to Local Policies and Practice. United National Settlements Program.

UN-Habitat (2016). Public Space II. New York: United National Conference on Housing and Sustainable Urban Development.

URT (1999). Land Acts No. 4 and 5 of 1999. Dar es Salaam: Government Printers.

URT (2000). National Human Settlements Development Policy. Dar es Salaam-Tanzania: Ministry of Lands and Human Settlements Development, the Government Printer.

URT (2007). The Urban Planning Act (Act No. 8 of 2007). Dar es Salaam: Government Printers.

URT (2012). The Urban Planning (Planning Space Standards) Regulations, 2013. Dar es Salaam: Government Printers.

URT (2015). The National Survey and Implementation of the 20,000 Plots. Dar es Salaam: Ministry of Lands and Human Settlements Development.

Woolley, H. (2003). Urban Open Spaces. London: Taylor \& Francis. https://doi.org/10.4324/9780203402146 